\title{
ФОРМИРОВАНИЕ ПРАВОВЫХ ОСНОВ СТРАТЕГИЧЕСКОГО ПЛАНИРОВАНИЯ В СФЕРЕ ЭНЕРГЕТИКИ В ЦЕЛЯХ ОБЕСПЕЧЕНИЯ ЭКОНОМИЧЕСКОЙ БЕЗОПАСНОСТИ РОССИЙСКОЙ ФЕДЕРАЦИИ
}

\section{FORMATION OF LEGAL BASES \\ FOR STRATEGIC PLANNING \\ IN THE ENERGY SECTOR IN ORDER \\ TO ENSURE THE ECONOMIC SECURITY \\ OF THE RUSSIAN FEDERATION}

A. Vasilchenko

Summary. The article deals with the formation of the legal framework for strategicplanninginthefield ofeconomics, in particular, one ofitssectors energy. The author uses both general scientific and special legal research methods, systemic, logical, dialectic, historical, comparative legal, observation and description, analysis of documents and other generally accepted methods of scientific knowledge. The author talks about the importance of strategic planning for efficient management and discusses the direct connection of strategic planning with ensuring the economic security of the country. The article highlights the main regulatory acts that form the basis of strategic planning in Russia, their features are considered and common features are highlighted.

Keywords: strategic planning, energy, energy security, economic security, energy strategy, White Paper, Roadmap, security, energy efficiency, energy.

\section{Обшие по^ожения}

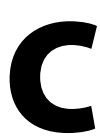

лово «стратегия» имеет древнегреческое происхождение, первоначальное его значение - «искусство полководца». Широкое распространение термин получил в 6-м веке нашей эры в восточно-римской терминологии и был переведен на другие европейские языки в 18 веке. С тех пор слово «стратегия» стало обозначать способ достижения отдаленной цели, включающий в себя совокупность тех или иных действий в определенной последовательности. Если рассматривать безопасность как состояние защищенности от различного рода угроз, логично предположить, что высокая эффективность реакции на угрозы возможна в тех случаях, когда вероятность наступления несущего угрозу события была спрогнозирована. Именно поэтому обеспечение безопасности, в том числе экономической, во многом зависит от того, как осуществляется стратегическое планирование в указанной сфере. Стратегическое планирование - это организационная управ-

\author{
Васильченко Анна Ивановна \\ К.ю.н., Санкт-Петербургский государственный \\ архитектурно-строительный университет \\ vasilcanna@yandex.ru
}

Аннотация. Целью исследования является изучение вопросов формирования правовых основ стратегического планирования в сфере экономики, В частности одной из ее отраслей - энергетики. В работе используются как общенаучные, так и специальные правовые методы исследования, а именно, системный, логический, диалектический, исторический, сравнительно-правовой, наблюдение и описание, анализ документов и другие общепринятые методы научного познания. Автор говорит о важности стратегического планирования для эффективного хозяйствования и о непосредственной связи стратегического планирования с обеспечением экономической безопасности страны. В статье освещены основные нормативно-правовые акты, составляющие основу стратегического планирования в России, рассмотрены их особенности и выделены общие признаки.

Ключевые слова: стратегическое планирование, энергетика, энергетическая безопасность, экономическая безопасность, энергетическая стратегия, Белая книга, Дорожная карта, обеспечение безопасности, энергетическая эффективность, энергия.

ленческая деятельность, в ходе которой происходит определение приоритетов, распределение ресурсов, а также оценка эффективности реализации стратегии и ее возможная корректировка в случае изменения обстоятельств. В процессе стратегического планирования необходимо найти ответ не только на вопрос «Куда?» (куда движется организация или государство в целом, какова стратегическая цель), но и «Как?» (как, каким образом цель должна быть достигнута).

В развитых странах стратегическое планирование лежит в основе обеспечения безопасности. Как правило, консолидация поставленных в ходе стратегического планирования задач происходит в итоговом документе, принимаемом на государственном уровне - в западных странах, таких как США, Великобритания, Франция, Австралия, такой документ носит название «Белая книга» («White paper»). В качестве приложения к Белым книгам зачастую разрабатывается Дорожная карта («Road тар») - документ, содержащий информацию о том, как 
достичь поставленных задач. В совокупности Белая книга и Дорожная карта играют роль ориентира для дальнейшего законотворчества, так как иные нормативные акты, принимаемые в целях обеспечения безопасности, должны вписываться в канву стратегического планирования.

Необходимость стратегического планирования в сфере энергетики продиктована значимостью энергетической отрасли для экономики. Более того, осмелимся утверждать, что энергетическая безопасность является непременным условием устойчивой экономики, в силу того, что без энергоресурсов невозможно осуществление никаких экономических процессов. Энергетическая безопасность прямо и непосредственно влияет на состояние экономической безопасности и, как следствие, безопасности национальной.

Стратегическое планирование в энергетике активно осуществляется в США и Евросоюзе. Утвержденные соответствующими органами власти энергетические стратегии формируют правовую основу для дальнейшего построения энергетического законодательства стран. Так, в Европейском союзе принята и действует Энергетическая стратегия до 2030 года [1] и долгосрочная энергетическая Дорожная карта до 2050 года [2]. Указанные акты служат камертоном для государств-членов ЕС, поскольку законодательство стран должно быть приведено в соответствие тем требованиям, которые предъявляются в целях реализации стратегических планов в энергетике.

\section{Правовые основы \\ стратегического п^анирования \\ в Российской Фехерации}

Что касается России, в советский период был наработан определенный опыт эффективного стратегического планирования в сфере экономики и энергетики. Достаточно вспомнить перспективный план развития народного хозяйства на основе электрификации страны, разработанный в 1920 году Государственной комиссией по электрификации России (ГОЭРЛО). Несмотря на то, что в начале 20 века еще не сложилась общепринятая ныне терминология, включающая понятия «экономическая безопасность», «энергетическая безопасность» можно заключить, что одной из главных целей разработки плана ГОЭРЛО было обеспечение энергетической независимости и безопасности страны. «Мы старались подойти к разрешению наших хозяйственных проблем с точки зрения быстрейшего устранения тех кризисов, не прекращающееся действие которых обусловливает переживаемую нами экономическую разруху» [3],-утверждали авторы плана, и в данном высказывании видится намерение устранить угрозы экономической безопасности страны, существовавшие на тот момент.
В настоящее время необходимость стратегического планирования прямо следует из текста конституционной нормы. Так, п. «е» ст. 71 Конституции РФ относит «установление основ федеральной политики и федеральные программы в области государственного, экономического, экологического, социального, культурного и национального развития Российской Федерации» [4] к федеральному ведению. Ведение (от слова «ведать»знать, иметь сведения о чём-либо; представлять, сознавать, отдавать отчет) подразумевает не только право федерального центра принимать решения в своей сфере ответственности, но и обязанность это делать. Таким образом, статья 71 Конституции устанавливает обязанность федерации проектировать основы федеральной политики и федеральные программы, а исполнение данной обязанности невозможно без осуществления стратегического планирования. Однако, в постперестроечный период вопросам стратегического планирования в сфере экономической безопасности не уделялось должного внимания, все ограничивалось лишь бюджетным планированием на трехлетний срок. Только 7 мая 2012 года был издан Указ Президента РФ № 596 «О долгосрочной государственной экономической политике» [5], положивший начало формированию правовых основ стратегического планирования в современной России.

Во исполнение Указа Президента РФ №596 был принят Федеральный закон Федеральный закон от 28.06.2014 N172-Ф3 «О стратегическом планировании в Российской Федерации» [6]. В статье 3 указанного закона впервые вводится понятие стратегического планирования. Согласно закону, стратегическое планирование носит системный характер; в качестве звеньев системы выступает прогнозирование, планирование, реализация, а также текущий и последующий контроль. В рамках системы принимаются документы стратегического планирования, закрытый перечень которых содержится в статье 11 Ф3 № 172. Поименованные в законе документы существуют в определенной иерархии, которая определена федеративным устройством России: на федеральном уровне разрабатываются документы по вопросам федерального ведения, на уровне субъектов РФ - по региональным вопросам, на муниципальном уровне - по вопросам местного значения. Следует отметить, что в законе речь идет именно о документах стратегического планирования, а не о нормативно-правовых актах. Объяснить логику законодателя можно тем, что понятия «документ» и «нормативно-правовой акт» соотносятся как общее и частное. Не углубляясь в сферу исследования теории права, отметим в целом, что нормативно-правовой акт - это документ особого рода, который содержит норму права, то есть правило поведения, воздействующее на отношения субъектов права и обязательное для исполнения. Именно поэтому к нормативно-правовым актам предъявляется ряд 
требований, относящихся к их форме и содержанию. В то же время, не всякий документ носит нормативный характер, то есть устанавливает правовую норму. Так, перечень документов стратегического планирования, представленный в Ф3 № 172, содержит ряд документов, не относящихся к числу нормативных актов, например, ежегодное послание Президента Российской Федерации Федеральному Собранию Российской Федерации, прогноз научно-технологического развития Российской Федерации, стратегический прогноз Российской Федерации и некоторые другие. Поскольку настоящая статья посвящена правовым основам стратегического планирования в сфере экономической безопасности, вышеуказанные и иные документы стратегического планирования, не относящиеся к числу нормативных актов подробно рассматриваться не будут.

Говоря о нормативных актах, прямо или косвенно влияющих на стратегическое планирование в сфере энергетики и экономической безопасности, в первую очередь следует назвать Концепцию долгосрочного социально-экономического развития Российской Федерации на период до 2020 года, утвержденную соответствующим распоряжением Правительства РФ [7]. Данная Концепция является первым в современной России актом подобного рода; содержание Концепции во многом посвящено вопросам безопасности - в тексте речь идет не только о безопасности национальной и экономической, но и о продовольственной, транспортной, энергетической, экологической, технологической безопасности. Стратегические направления применительно к сфере экономической безопасности содержит раздел IV Концепции «Развитие экономических институтов и поддержание макроэкономической стабильности». Концепция пережила несколько редакций, однако о большей части осталась невыполненной.

Очередным шагом к построению правых основ стратегического планирования стало издание Указа Президента РФ от 31.12.2015 N683, которым была утверждена Стратегия национальной безопасности Российской Федерации [8]. Именно в данном нормативном акте экономическая безопасность впервые названа одной из стратегических целей; кроме того, была сделана попытка обозначить факторы экономической безопасности, а также выделить основные направления противодействия существующим и будущим угрозам. Стратегию национальной безопасности можно назвать рамочным стратегическим актом, в котором нашел отражение комплексный подход к вопросу национальной безопасности. Утверждение Стратегии национальной безопасности подготовило почву для принятия нормативного акта, утвердившего Стратегию экономической безопасности Российской Федерации на период до 2030 года [9]. Именно в данном акте впервые были изложены опреде- ления базовых понятий, таких как «экономическая безопасность», «обеспечение экономической безопасности», «угроза экономической безопасности», «экономический суверенитет» и ряд других. Кроме того, в числе положительных моментов, характеризующих Стратегию экономической безопасности, следует назвать систему конкретно изложенных целей и задач, а также вызовов и угроз экономической безопасности. По сравнению с иными документами подобного рода, Стратегия в целом носит более детальный характер.

Рассмотренные акты стратегического планирования относятся к федеральному уровню и носят надотраслевой характер и не могут учитывать специфику обеспечения экономической безопасности в отдельных отраслях экономики. Однако Ф3 «О стратегическом планировании в РФ» наделяет профильные министерства обязанностью осуществлять целеполагание в том числе по отраслевому принципу. В настоящий момент в России активно формируется система отраслевых стратегий развития (например, Стратегия развития электронной промышленности, Стратегия развития минерально-сырьевой базы России, Стратегия повышения финансовой грамотности и иные). Важнейшее значение имеет принятие в ближайшей перспективе Энергетической стратегии России до 2035 года [10], которая разрабатывается достаточно длительное время. Проект Энергетической стратегии-2035 содержит цели и направления развития энергетики России, отражает основные риски и угрозы и, что немаловажно, устанавливает количественные показатели реализации стратегии, которые должны быть достигнуты к 20135 году. Таким образом, будучи утвержденной, Энергетическая стратегия-2035 станет важнейшим отраслевым актом стратегического планирования, выполнение которого будет напрямую влиять на поддержание уровня экономической безопасности страны.

\section{Выво $\triangle \mathrm{b}$}

В настоящее время в России наблюдается активное формирование системы нормативно-правовых актов, регламентирующих вопросы стратегического планирования в сфере безопасности. Необходимость принятия нормативных актов такого рода следует из конституционной нормы, устанавливающей обязанность федерального центра осуществлять планирование федеральной политики и разработку федеральных программ. В настоящее время система актов стратегического планирования применительно к сфере экономической безопасности представлена Ф3 «О стратегическом планировании в Российской Федерации», который устанавливает структуру актов стратегического планирования федерального, регионального и местного уровня. На основании и во исполнение указанного федерального за- 
кона подзаконными актами Президента и Правительства утверждены Стратегия национальной безопасности РФ, Стратегия экономической безопасности РФ, Концепция социально-экономического развития РФ. Перечисленные акты составляют правовые основы стратегического планирования в сфере экономической безопасности и объединены рядом общих черт, выделяющих их из массы иных актов: все они носят рамочный характер, декларативный характер, надотраслевой характер. Рамочный характер актов стратегического планирования выражается в наличии определенной концепции, реализация которой предусматривает различные варианты действий в зависимости от существующих условий. Декларативный характер подразумевает, что большинство норм, входящих в акт стратегического планирования, носят программный характер, определяют цели и задачи и не конкретизированы в силу отсутствия диспозиции нормы. Кроме того, акты стратегического планирования имеют надотраслевой, универсальный характер, что означает не только возможность, но и необходимость их применения к различным отраслям экономики. Что касается отраслевых актов стратегического планирования, их система в сфере энергетики еще не сложилась окончательно. Тем не менее, необходимые правовые предпосылки созданы, а тенденция к дальнейшему совершенствованию правовых основ достаточно устойчивая. Ключевым моментом здесь станет утверждение новой Энергетической стратегии России - 2035.

\section{ЛИТЕРАТУРА}

1. Официальный сайт Европейской комиссии [Электронный ресурс]. Режим доступа: https://ec.europa.eu/clima/policies/strategies/2030_en (дата обращения: 26.03.2020).

2. Официальный сайт Европейской комиссии [Электронный ресурс]. Режим доступа: https://ec.europa.eu/clima/policies/strategies/2050_en (дата обращения: 26.03.2020).

3. План электрификации РСФСР. Введение к докладу 8 съезду Советов Государственной Комиссией по электрификации России. Государственно- техническое издательство М. 1920. С. 230.

4. Конституция Российской Федерации (принята всенародным голосованием 12.12.1993) // Собрание законодательства PФ, 04.08.2014, N31, ст. 4398.

5. Указ Президента РФ от 7 мая 2012 г. N596 «0 долгосрочной государственной экономической политике» // Собрание законодательства Российской Федерации от 7 мая 2012 г. $\mathrm{N} 19$ ст. 2333

6. Федеральный закон от 28 июня 2014 г. N172-Ф3 «0 стратегическом планировании в Российской Федерации» // Собрание законодательства Российской Федерации от 30 июня 2014 г. N26 (часть I) ст. 3378.

7. Распоряжение Правительства РФ от 17.11.2008 N1662-р «0 Концепции долгосрочного социально-экономического развития Российской Федерации на период до 2020 года» // Собрание законодательства РФ», 24.11.2008, N47, ст. 5489.

8. Указ Президента РФ от 31 декабря 2015 г. 683 «0 Стратегии национальной безопасности Российской Федерации» // Собрание законодательства Российской Федерации от 4 января 2016 г. N1 (часть ІІ) ст. 212.

9. Указ Президента РФ от 13 мая 2017 г. N208 «0 Стратегии экономической безопасности Российской Федерации на период до 2030 года» // Собрание законодательства Российской Федерации от 15 мая 2017 г. N20 ст. 2902.

10. Энергетическая стратегия России до 2035 года [Электронный ресурс]. Режим доступа: http://www.energystrategy.ru/ab_ins/source/ES-2035_09_2015.pdf (дата обращения: 26.03.2020). 